\title{
Front Matter: Volume 10149
}

, "Front Matter: Volume 10149," Proc. SPIE 10149, Advanced Etch Technology for Nanopatterning VI, 1014901 (21 April 2017); doi: $10.1117 / 12.2279253$

SPIE. Event: SPIE Advanced Lithography, 2017, San Jose, California, United States 


\title{
PROCEEDINGS OF SPIE
}

\section{Advanced Etch Technology for Nanopatterning VI}

\author{
Sebastian U. Engelmann \\ Richard S. Wise \\ Editors
}

27 February - 1 March 2017

San Jose, California, United States

Cosponsored by

Lam Research Corporation (United States)

Published by

SPIE 
The papers in this volume were part of the technical conference cited on the cover and title page. Papers were selected and subject to review by the editors and conference program committee. Some conference presentations may not be available for publication. Additional papers and presentation recordings may be available online in the SPIE Digital Library at SPIEDigitallibrary.org.

The papers reflect the work and thoughts of the authors and are published herein as submitted. The publisher is not responsible for the validity of the information or for any outcomes resulting from reliance thereon.

Please use the following format to cite material from these proceedings:

Author(s), "Title of Paper," in Advanced Etch Technology for Nanopatterning VI, edited by Sebastian U. Engelmann, Richard S. Wise, Proceedings of SPIE Vol. 10149 (SPIE, Bellingham, WA, 2017) Seven-digit Article CID Number.

ISSN: 0277-786X

ISSN: 1996-756X (electronic)

ISBN: 9781510607491

ISBN: 9781510607507 (electronic)

Published by

SPIE

P.O. Box 10, Bellingham, Washington 98227-0010 USA

Telephone +1 3606763290 (Pacific Time) · Fax +1 3606471445

SPIE.org

Copyright (c) 2017, Society of Photo-Optical Instrumentation Engineers.

Copying of material in this book for internal or personal use, or for the internal or personal use of specific clients, beyond the fair use provisions granted by the U.S. Copyright Law is authorized by SPIE subject to payment of copying fees. The Transactional Reporting Service base fee for this volume is $\$ 18.00$ per article (or portion thereof), which should be paid directly to the Copyright Clearance Center (CCC), 222 Rosewood Drive, Danvers, MA 01923. Payment may also be made electronically through CCC Online at copyright.com. Other copying for republication, resale, advertising or promotion, or any form of systematic or multiple reproduction of any material in this book is prohibited except with permission in writing from the publisher. The CCC fee code is 0277-786X/17/\$18.00.

Printed in the United States of America.

Publication of record for individual papers is online in the SPIE Digital Library.

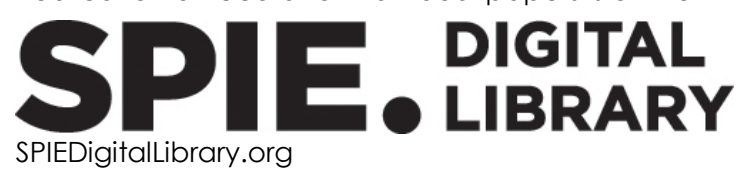

Paper Numbering: Proceedings of SPIE follow an e-First publication model. A unique citation identifier (CID) number is assigned to each article at the time of publication. Utilization of CIDs allows articles to be fully citable as soon as they are published online, and connects the same identifier to all online and print versions of the publication. SPIE uses a seven-digit CID article numbering system structured as follows:

- The first five digits correspond to the SPIE volume number.

- The last two digits indicate publication order within the volume using a Base 36 numbering system employing both numerals and letters. These two-number sets start with 00, 01, 02, 03, 04, $05,06,07,08,09,0 A, 0 B \ldots$. OZ, followed by 10-1Z, 20-2Z, etc. The CID Number appears on each page of the manuscript. 


\title{
Contents
}

\author{
$\checkmark \quad$ Authors \\ vii Conference Committee \\ ix Introduction
}

PATTERNING TECHNIQUES FOR ADVANCED TECHNOLOGY NODES

1014908 Self-aligned block technology: a step toward further scaling [10149-7]

PATTERNING CHALLENGES IN NANOPHOTONIC STRUCTURES

10149 OD Silicon photonics and challenges for fabrication (Invited Paper) [10149-13]

10149 OF Reducing line Edge Roughness in Si and SiN through plasma etch chemistry optimization for photonic waveguide applications [10149-15]

PATTERNING MATERIALS AND ETCH: JOINT SESSION WITH CONFERENCES 10146 AND 10149

$10149 \mathrm{OH} \quad$ Plasma-assisted thermal atomic layer etching of $\mathrm{Al}_{2} \mathrm{O}_{3}$ [10149-17]

10149 Ol Self-aligned quadruple patterning using spacer on spacer integration optimization for N5 [10149-18]

10149 0J Directed self-assembly patterning strategies for phase change memory applications [10149-19]

NOVEL PLASMA PATTERNING TECHNIQUES

10149 OK Nanoimprint, DSA, and multi-beam lithography: patterning technologies with new integration challenges (Invited Paper) [10149-20]

$10149 \mathrm{OL}$ Overview of several applications of chemical downstream etching (CDE) for IC manufacturing: advantages and drawbacks versus WET processes (Invited Paper) [10149-21]

10149 OM Study of selective chemical downstream plasma etching of silicon nitride and silicon oxide for advanced patterning applications [10149-22] 
10149 ON Co-optimization of lithographic and patterning processes for improved EPE performance (Invited Paper) [10149-25]

1014900 Self-aligned blocking integration demonstration for critical sub-40nm pitch Mx level patterning [10149-26]

\section{PATTERNING SOLUTIONS FOR EMERGING PRODUCTS}

$101490 Q \quad$ Guiding gate-etch process development using 3D surface reaction modeling for $7 \mathrm{~nm}$ and beyond (Invited Paper) [10149-36]

10149 OR Plasma processing of III-V materials for energy efficient electronics applications (Invited Paper) [10149-29]

10149 OS Design and fabrication of resonator-QWIP for SF 6 gas sensor application [10149-30]

\section{POSTER SESSION}

10149 OT Spin-on metal oxide materials for N7 and beyond patterning applications [10149-8]

10149 OU Improvement of a block co-polymer (PS-b-PDMS) template etch profile using amorphous carbon layer [10149-24]

10149 OX A method to accelerate creation of plasma etch recipes using physics and Bayesian statistics [10149-33]

10149 oY The line roughness improvement with plasma coating and cure treatment for 193nm lithography and beyond [10149-34]

$101490 Z$ The application of advanced pulsed plasma in Fin etch loading improvement [10149-35]

1014910 Facile fabrication of Si-based nanostructures [10149-37] 


\section{Authors}

Numbers in the index correspond to the last two digits of the seven-digit citation identifier (CID) article numbering system used in Proceedings of SPIE. The first five digits reflect the volume number. Base 36 numbering is employed for the last two digits and indicates the order of articles within the volume. Numbers start with 00, 01, 02, 03, 04, 05, 06, 07, 08, 09, OA, OB...0Z, followed by 10-1Z, 20-2Z, etc.

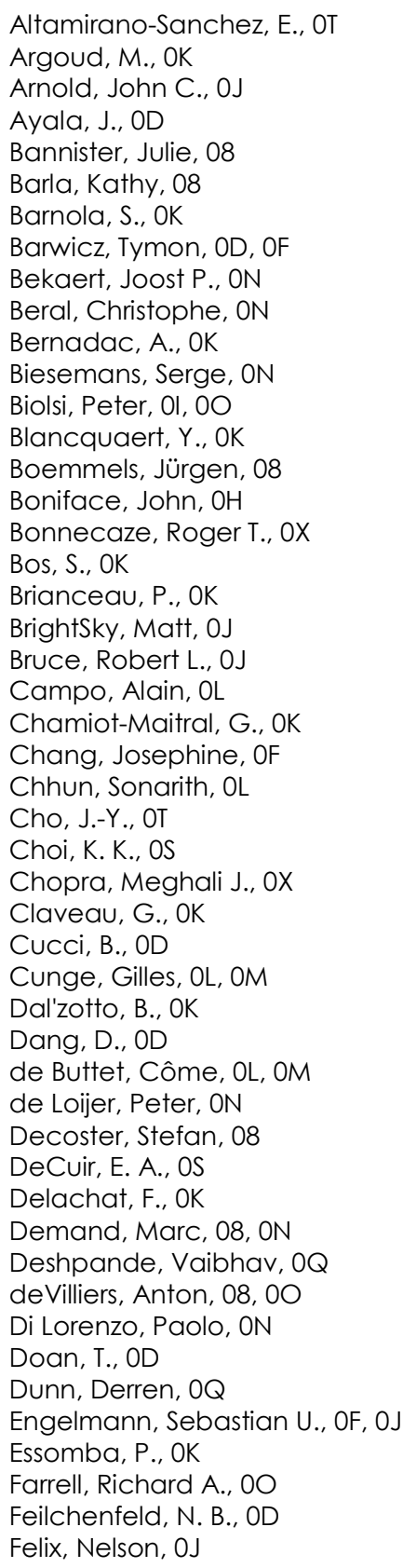




\author{
Mao, Ming, ON \\ Marchack, Nathan, OF \\ Maslow, Mark J., ON \\ Massin, Thomas, OL \\ Masuda, Takeshi, OJ \\ Maury, Patrick, OL \\ May, M., OK \\ Mckenzie, D., OT \\ McLean, K., OD \\ Meng, Lingkuan, 10 \\ Metz, Andrew W., ON, 00 \\ Millar, David, OR \\ Miyazoe, Hiroyuki, oJ \\ Mohanty, Nihar, 08, 0l, 00 \\ Morikita, Shinya, ON \\ Mullen, S., OT \\ Nafus, Kathleen, 08 \\ Nouri, L., OK \\ Nummy, K., OD \\ Oh, JiSoo, OU \\ Oh, Jong Sik, OU \\ Okada, Soichiro, ON \\ Olver, K. A., OS \\ O'Meara, David, OI \\ Orcutt, Jason S., OD, OF \\ Oulmane, Mohamed, $0 Q$ \\ Padmanaban, M., OT \\ Pain, L., OK \\ Pan, Yang, $\mathrm{OH}$ \\ Papalia, John M., OJ \\ Peralagu, Uthayasankararan, OR \\ Petermann, C., OT \\ Petit-Etienne, Camille, OM \\ Pimenta Barros, P., OK \\ Piumi, Daniele, 08, 0T \\ Porth, B., OD \\ Possemé, N., OK \\ Pourteau, M. L., OK \\ Pradelles, J., OK \\ Prévost, Emilie, OL, OM \\ Rahman, D., OT \\ Raley, Angélique, $0 \mathrm{l}, 0 \mathrm{O}$ \\ Ranjan, Alok, $0 Q$ \\ Rosenberg, J., OD \\ Ryckaert, Julien, 08 \\ Sarrazin, A., OK \\ Scheer, Steven, 08 \\ Sebaai, F., OT \\ Servin, I., OK \\ Smith, Jeffrey T., 08, 00 \\ Song, SeungWon, OU \\ Sowinski, Z., OD \\ Sporre, John R., OQ \\ Stricker, A. D., OD \\ Sun, J., OS \\ Sun, Xinghua, 00 \\ Sung, Daln, oU \\ Suu, Koukou, OJ \\ Tallaron, C., OK \\ Tang, Hao, OJ
}

Tapily, Kandabara, Ol

Teyssedre, H., OK

Thayne, Iain, OR

Thibaut, Sophie, 0 I

Timoshkov, Vadim, ON

Tiron, R., OK

Tokei, Zsolt, 08

Tsai, HsinYu, OJ

Vahedi, Vahid, $\mathrm{OH}$

Vallier, Laurent, OL, OM

Vega Gonzalez, Victor, 08

Ventzek, Peter, $0 Q$

Verma, Rahul, OX

Whiting, C., OD

Willets, C., OD

Willson, C. G., OX

Wilson, Chris, 08

Wolfer, E., OT

Xiao, Fang-Yuan, $\mathrm{OZ}$

Xiong, C., OD

Yaegashi, Hidetami, ON

Yan, Jiang, 10

Yao, H., OT

Yeom, GeunYoung, OU

Yim, SoonMin, OU

Yu, C., OD

Yum, S., OD

Zhang, Hai-Yang, $\mathrm{OY}, \mathrm{OZ}$

Zheng, Erhu, OY

Zhu, Yu, OJ

Zoll, Stephane, OL 


\title{
Conference Committee
}

\author{
Symposium Chair
}

Bruce W. Smith, Rochester Institute of Technology (United States)

Symposium Co-Chair

Will Conley, Cymer, An ASML Company (United States)

Conference Chair

Sebastian U. Engelmann, IBM Thomas J. Watson Research Center (United States)

Conference Co-Chair

Richard S. Wise, Lam Research Corporation (United States)

Conference Program Committee

Efrain Altamirano-Sánchez, IMEC (Belgium)

Julie Bannister, Tokyo Electron America, Inc. (United States)

Sang-Hoon Cho, SK Hynix, Inc. (Korea, Republic of)

Maxime Darnon, LTM CNRS (France)

Eric A. Hudson, Lam Research Corporation (United States)

Catherine B. Labelle, GLOBALFOUNDRIES Inc. (United States)

Nae-Eung Lee, Sungkyunkwan University (Korea, Republic of)

Qinghuang Lin, IBM Thomas J. Watson Research Center (United States)

Gottlieb S. Oehrlein, University of Maryland, College Park (United States)

Erwine Pargon, CNRS/LTM (France)

Nicolas Posseme, CEA-LETI (France)

Ricardo Ruiz, HGST (United States)

Seiji Samukawa, Tohoku University (Japan)

Robert Turkot, Intel Corporation (United States)

Jeff Xu, Qualcomm Technologies Inc. (United States)

Anthony Yen, TSMC Taiwan (Taiwan)

Ying Zhang, Applied Materials, Inc. (United States) 
Opening Remarks

Sebastian U. Engelmann, IBM Thomas J. Watson Research Center (United States)

1 Keynote Session

Catherine Labelle, GLOBALFOUNDRIES Inc. (United States)

Qinghuang Lin, IBM Thomas J. Watson Research Center (United States)

2 Patterning Techniques for Advanced Technology Nodes

Ying Zhang, Applied Materials, Inc. (United States)

Efrain Altamirano-Sánchez, IMEC (Belgium)

3 Advanced Plasma Process Control

Eric A. Hudson, Lam Research Corporation (United States)

Julie Bannister, Tokyo Electron America, Inc. (United States)

4 Patterning Challenges in Nanophotonic Structures

Maxime Darnon, CNRS-LN2 (France)

Julie Bannister, Tokyo Electron America, Inc. (United States)

5 Patterning Materials and Etch: Joint Session with Conferences 10146 and 10149

Qinghuang Lin, IBM Thomas J. Watson Research Center (United States)

Sebastian U. Engelmann, IBM Thomas J. Watson Research Center (United States)

6 Novel Plasma Patterning Techniques

Efrain Altamirano-Sánchez, IMEC (Belgium)

Eric A. Hudson, Lam Research Corporation (United States)

7 Litho Etch Process Interaction: Joint Session with Conferences 10147 and 10149

Richard S. Wise, Lam Research Corporation (United States)

Yuri Granik, Mentor Graphics Corporation (United States)

8 Patterning Solutions for Emerging Products

Maxime Darnon, CNRS-LN2 (France)

Qinghuang Lin, IBM Thomas J. Watson Research Center

(United States) 


\section{Introduction}

This proceedings volume contains accepted papers from the SPIE conference on Advanced Etch Technology for Nano-patterning VI (The SPIE Etch conference) held as part of the International Symposium on Advanced Lithography, held 26 February - 2 March 2017, in San Jose, California, United States. These proceedings papers cover the latest advances in the wide field of etch and nano-patterning technology and offer a glimpse at the state-of-the-art developments of this important field of semiconductor technology.

This year's SPIE Etch conference continued the fine tradition of having a wide international representation and attracted many researchers from related fields. For this year, our conference spanned three days, with the papers divided into eight sessions (listed below) which continued to garner tremendous interest among conference attendees:

Keynote Session

Patterning Techniques for Advanced Technology Nodes

Advanced Plasma Control

Patterning Challenges in Nanophotonic Structures

Patterning Materials and Etch: Joint Session with Conferences 10146 and 10149

Novel Plasma Patterning Techniques

Litho Etch Process Interaction: Joint Session with Conferences

10147 and 10149

Patterning Solutions for Emerging Products

The widely recognized challenges in extension of Moore's Law have driven the industry toward collaboration across process modules. This year, the Etch conference focused on strengthening this collaboration with two well-attended joint sessions on Patterning Materials and Etch with the Advances in Patterning Materials and Processes conference (volume 10146) and on Litho Etch interactions with the Optical Microlithography conference (volume 10147).

The keynote session of the Etch conference again drew very big crowds, where some of the most important fundamental issues faced in the world of nanopatterning and etch, as well as device fabrication in a post-classical scaling world, were discussed. First hints at new directions for patterning applications were presented at the nanophotonic patterning session, where patterning applications for optical devices and features were discussed. We hope that these proceedings proves valuable to the many patterning scientists and engineers working in the fast-moving semiconductor industry. We also hope that it serves as a useful reference for those who are interested in nanofabrication, micro- and 
nano-fluidics, micro- and nano-photonics, Micro-Electro-Mechanical Systems (MEMS), BioMEMS, organic electronics, advanced packaging, and bio-chips.

We thank the authors, particularly the invited speakers, for their valuable contributions to the conference and proceedings volume. The SPIE Etch conference is highly regarded among the worldwide patterning community; which recognizes the high quality of our talks and proceedings papers. We also thank members of the organizing committee for their dedication and hard work to help maintain a high quality of this conference. We are also grateful to LAM Research Corporation (United States) for their generous financial support.

Finally, we extend our sincere thanks to the SPIE staff for their tireless efforts and their meticulous organizational skills in helping make this year's SPIE Etch conference a success and in assembling and publishing this proceedings volume.

Sebastian U. Engelmann Richard S. Wise 